\title{
NATURAL HISTORY NOTE \\ Pleistocene bats (Mammalia, Chiroptera) from Grotta dei Pipistrelli (southeastern Sicily, Italy). Preliminary report.
}

\author{
Maria Teresa Spena ${ }^{1}$, Paolo Agnelli ${ }^{2}$, Jessica Di Maita ${ }^{1}$, Rosario Grasso ${ }^{1}$, Agatino Reitano ${ }^{3}$, Corrado \\ Santoro ${ }^{4}$, Leonardo Salari ${ }^{5, *}$
}

\author{
${ }^{1}$ Dipartimento di Scienze \\ Biologiche, Geologiche ed. \\ Ambientali, Università degli \\ Studi di Catania, Via Androne \\ 81 - 95124 Catania, Italy. \\ ${ }^{2}$ Museo di Storia Naturale \\ dell'Università degli Studi di \\ Firenze, Sezione di Zoologia \\ "La Specola", Via Romana 17 \\ 50125 Firenze, Italy. \\ ${ }^{3}$ Museo di Storia Naturale \\ i Comiso, Via degli Studi 9 - \\ 97013 Comiso (RG), Italy. \\ ${ }^{4}$ Dipartimento di Matematica \\ e Informatica, Università degli \\ Studi di Catania, Viale Andrea \\ Doria 6 - 95125 Catania, Italy. \\ ${ }^{5}$ Dipartimento Scienze della \\ Terra, "Sapienza" Università di \\ Roma (external collaborator), \\ Piazzale Aldo Moro, 5 - 00185 \\ Roma, Italy \\ * Corresponding author: \\ leonardosalari@virgilio.it \\ DOI: https://doi.org/10.14709/
} BarbJ.10.1.2017.06

\begin{abstract}
Seven species of bats (Mammalia, Chiroptera) have been identified in the fossil assemblage from the Grotta dei Pipistrelli (Sortino, Sicily, Italy): Rhinolophus ferrumequinum, R. euryale, R. mehelyi, Myotis myotis, M. blythii, M. capaccinii and Miniopterus schreibersii. All the recognized species are presently part of the Italian bat fauna; currently, they occur in Sicily and probably still live in the cave today. In Sicily, fossils of Chiroptera are poorly known and this work is the second study of a Pleistocene bats assemblage. In this paper, the first instance of $R$. euryale in Sicily, and of $M$. myotis and $M$. blythii for the central Mediterranean islands from Pleistocene are reported.
\end{abstract}

\section{RESUMEN}

Siete especies de murciélagos (Mammalia, Chiroptera) han sido identificadas en la asociación fósil de Grotta dei Pipistrelli (Sortino, Sicilia, Italia): Rhinolophus ferrumequinum, R. euryale, R. mehelyi, Myotis myotis, M. blythii, M. capaccinii y Miniopterus schreibersii. Todas las especies identificadas forman parte de la fauna italiana actual de murciélagos, están presentes en Sicilia y probablemente a día de hoy habitan la cavidad. Los fósiles de quirópteros son poco conocidos en Sicilia, siendo éste el segundo estudio relacionado con una asociación de murciélagos del Pleistoceno. En este artículo se muestra, por primera vez, la presencia en el Pleistoceno de $R$. euryale en Sicilia y de $M$. myotis y M. blythii en las islas del Mediterráneo central.

Keywords: chiroptera, ossiferous breccias, Pleistocene, Sicily, paleoecology, paleobiogeography.

Palabras clave: chiroptera, brechas fosilíferas, Pleistoceno, Sicilia, paleoecología, paleobiogeografía.

received: June, 20th 2017

accepted: September, 19th 2017

Bat fossils are still poorly known in the world and specifically in Italy: this work is the second study of a Pleistocene bats assemblage in Sicily. The lack of palaeontological interest in bats is probably due to the bradytelic evolution of these flying mammals that makes them almost useless for the biochrological studies. However, Chiroptera are very useful for palaeoecological and palaeoclimatic reconstructions (see Salari \& Kotsakis 2011, and references therein). A summary of the knowledge on the bat findings from the Oligocene to the Quaternary in the Italian region (including Maltese archipelago) was presented by Tata \& Kotsakis (2005), and afterwards updated by Salari \& Di Canzio (2009), Salari (2010) and Lanza (2012).

In this paper the preliminary analyses of the bat fossil samples collected in the Grotta dei Pipistrelli (literally, Cave of the Bats), located in the Natural Reserve "Pantalica, Valle dell'Anapo e Torrente Cava Grande" (Sortino, Syracuse, Sicily; Fig. 1A) are presented.
The Grotta dei Pipistrelli is so called because it hosts a considerable number of bats (Caruso \& Grasso 1996). The karst cavity opens on a rocky wall overhanging the Calcinara stream, about $10 \mathrm{~m}$ from the watercourse (Fig. 2), in the Miocene "Calcari di Siracusa" formation (Grasso \& Lentini 1982, Schilirò et al. 2002). The cavity has a sub-horizontal development with a 7.3\% WE average slope and it has been explored for about $260 \mathrm{~m}$ (Fig. 1B), between the entrance of the cave (234 $\mathrm{m}$ a.s.l.), to the left of the Calcinara stream, and the ending point ( $253 \mathrm{~m}$ a.s.l.), where a thick layer of detritus blocks the duct. At the entrance, the cave has a large opening that quickly shrinks into a funnel that enters into a first room. A gallery links the room to a large hall called "Sala del Guano", with a 15 m high vault consisting of three domes, which currently host a huge bat colony. The cavity continues with a series of galleries and small dome halls, and it is interrupted in a large terminal hall, where it ends in a duct enclosed by coarse detritus (Schilirò 2007, Grasso et al. in press). 


\section{GROTTA DEI PIPISTRELLI}

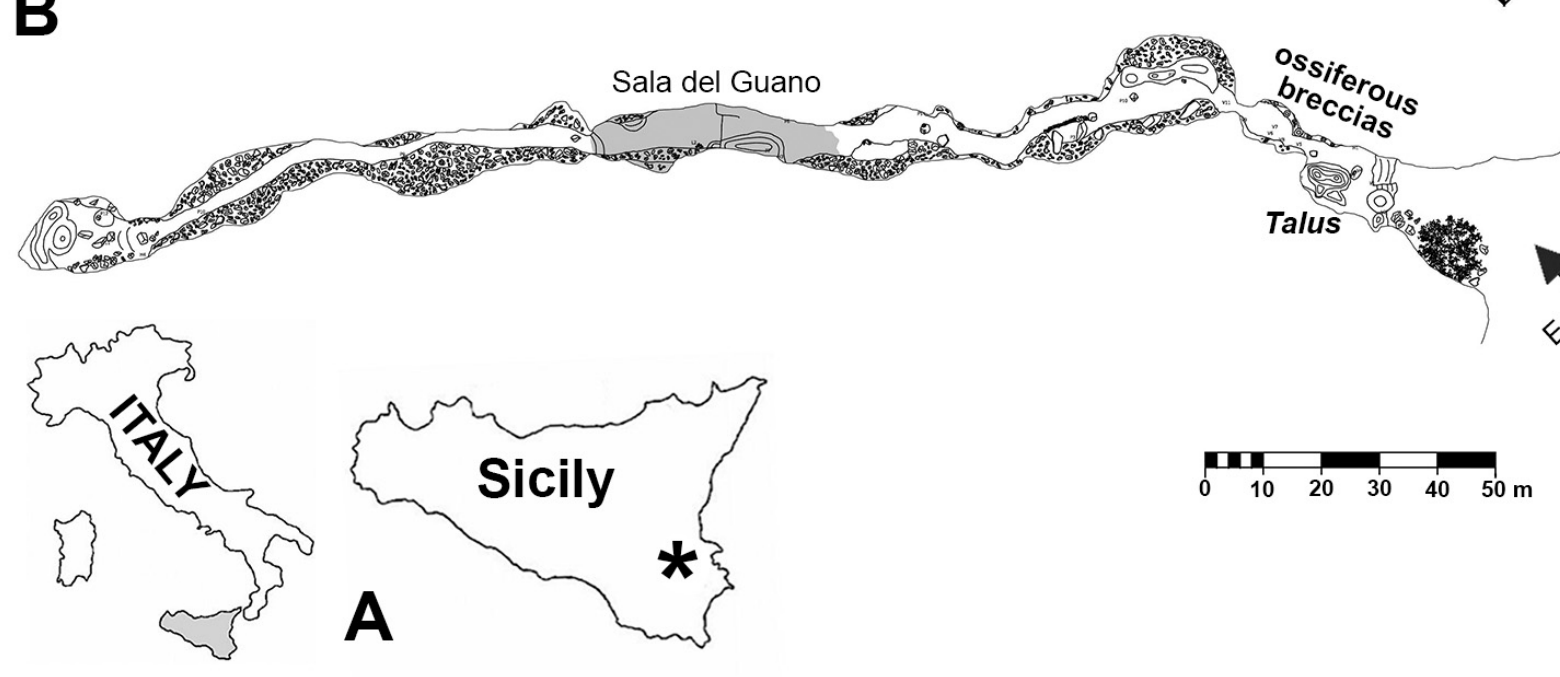

Fig. 1 - A) Location of the site: the asterisk indicates the Grotta dei Pipistrelli, near Sortino (Syracuse, Sicily, Italy); B) Plan of the cave.

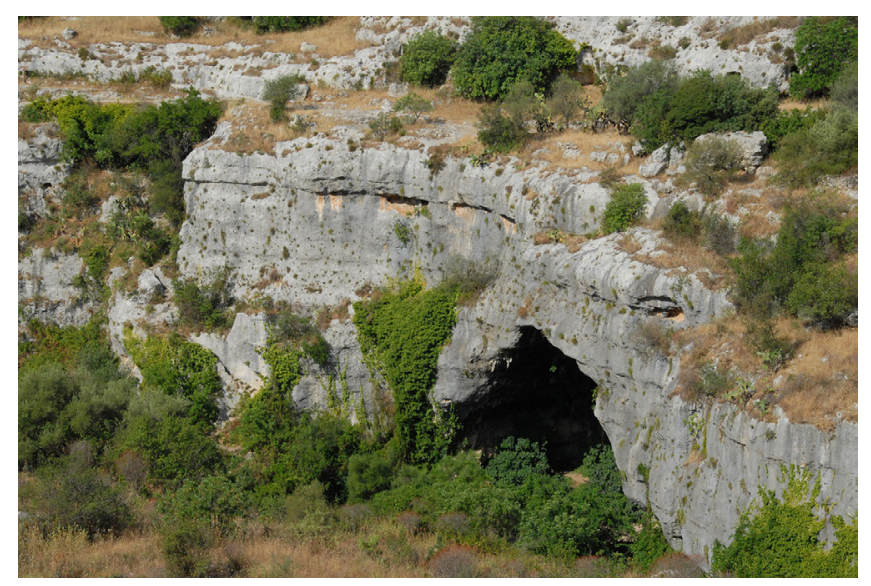

Fig. 2 - Grotta dei Pipistrelli (Sicily, Italy): entrance of the cave (photo by M.T. Spena).

Grotta dei Pipistrelli is mostly known for its large colonies of bats, which by number and importance are among the most numerous in Sicily, and it is the only cave, to date, systematically monitored (Spena et al. 2013, Grasso et al. in pres). Following the methodologies proposed by Agnelli et al. (2006), in January 2012 a monitoring programme started to identify the species, estimate the number of specimens and their seasonality. The following taxa were observed: Rhinolophus ferrumequinum, $R$. euryale, R. hipposideros, Myotis myotis vel blythii, M. capaccinii and Miniopterus schreibersii (see Spena et al. 2013, Grasso et al. in press). Among them, M. schreibersii and the greats Myotis are dominant, while the Rhinolophidae are the rarest. $R$. mehelyi is presumably present in low number of specimens (Caruso \& Grasso 1996, Spena et al. 2013, Grasso et al. in press). The maximum number of occurrences (taking into account all the species together) was recorded in summer (over 9,000 in July 2013), while in winter only a few hundred specimens of the genus Rhinolophus were observed. The finding of numerous juveniles in summer makes it possible to hypothesize that those of the Grotta dei Pipistrelli are primarily reproductive colonies (Spena et al. 2013, Grasso et al. in press).

In 1996 it was noticed that the walls of the talus (particularly the right wall) had several ossiferous breccias containing many small vertebrate remains (Aves, Rodentia, Soricomorpha and mostly Chiroptera). The sediments close to the right wall also contained small vertebrate remains, an elephant tusk, attributable to Palaeoloxodon mnaidriensis, and some bone remains of unidentified Cervidae. From 2014 to 2016, several campaigns on fossil remains collection were conducted by the authors (particularly JDM, RG, MTS). The research, authorized by the Regional Department of Agriculture, Rural Development and Mediterranean Fisheries of the Sicily Region, aimed to unveil the palaeoecological, palaeobiogeographical, microclimatic and biochronological information provided by the bat remains (and other Vertebrate fossils) recovered in the fossil assemblage from the Grotta dei Pipistrelli.

The sampling area, i.e. the right wall of the talus and the soil close to it, was subdivided into 25 sections of 1 $\mathrm{m}$, associated to a quoted line, in order to relate to depth each collected specimen and each related sample of soil and breccias. Each sample was identified with a progressive number and recorded with its section coordinates and depth. With the use of a laser scanner (Hokuyo URG-04LXUG01), a geometric survey of the sampled cave portion was conducted, to create a three-dimensional digital model (using the "Blender" program) as near as possible to the real shape (Fig. 3). The 21 specimens collected on sight at the right wall surface were washed in water, rinsed and then dried; the breccias (7 samples) were dissolved in acetic acid, then filtered, using 1.60 and $0.63 \mathrm{~mm}$ sieves and washed abundantly in water; 10 soil samples were sifted into water in the laboratory and then dried. 
Among the specimens collected on sight there were several complete or sub-complete skulls referable to Myotis myotis vel blythii. Some mandibles and humeri could be attributed to the same taxon and to $R$. ferrumequinum and M. schreibersii.

Selected skeletal elements (maxillae, mandibles, humeri) from the soil samples n. 23 and n. 25 (about 180 specimens) were compared with osteological material, both fossil and recent, stored in the Department of Earth Sciences of the "Sapienza" University of Rome and in the Department of Geological Sciences of the "Roma Tre" University. Morphological and morphometric observations and the dichotomous keys given by Felten et al. (1973), Sevilla García (1988), Niethammer \& Krapp (2001), Salari (2004) and Lanza (2012) were also consulted. In particular, the distinction between the middle-sized rhinolophid species ( $R$. euryale, $R$. blasii, $R$. mehelyi and, eventually, $R$. birzebbugensis) was focused on the morphology of upper canine, first and second upper molar, anterior and posterior lower premolar (Sevilla García 1988, Lanza 2012, Salari et al. 2013) and the styloid process of the humerus (Felten et al. 1973, Salari et al. 2013). The distinction between M. myotis and M. blythii was performed mainly on the talonid of the third lower molar, which is more reduced in M. myotis (see Topál \& Tusnadi 1963, Mein 1975, Sevilla García 1988, Salari \& Silvestri 2015). The analysis was performed with a stereoscopic microscope Nikon SMZ-U in the Department of Geological Sciences of the "Roma Tre" University; measurements and photographs were taken with a Leika DFC290 system using the Leica Application Suite software.

The following species were identified (Fig. 4): $R$. ferrumequinum, $R$. euryale, $R$. mehelyi, M. myotis, M. blythii, $M$. capaccinii and $M$. schreibersii. Several very fragmented elements were attributed to Rhinolophus euryale vel mehelyi, to Myotis myotis vel blythii or to unidentified Chiroptera. In the fossil bat assemblage from the Grotta dei Pipistrelli all recognized species are still part of the Italian bat fauna (Agnelli et al. 2006, Lanza 2012); they occur in Sicily (Agnelli et al. 2008) and probably they are all species still roosting in the cave today (Spena et al. 2013, Grasso et al. 2013).

Fossil remains of the identified species are known since Early or Middle Pleistocene in Italy (Tata \& Kotsakis 2005, Salari \& Di Canzio 2009, Salari 2010, Lanza 2012). From some samples collected in the ossiferous breccias on the wall surface and from the soil sample n. 25 some mandibles of Crocidura cf. sicula, Microtus (Terricola) ex gr. savii and Apodemus cf. sylvaticus were found, micromammal species that first occurred in Sicily in the San Teodoro-Pianetti Faunal Complex, referred to the Late Pleistocene (Marine Isotope Stages 4 and 3; see Bonfiglio et al. 2001, 2004). This Faunal Complex also records the last occurrences of Palaeoloxodon mnaidriensis (see Bonfiglio et al. 2001, 2004), and it probably represents the lower chronological limit for the deposition of the bone remains in the Grotta dei Pipistrelli.

R. ferrumequinum, R. mehelyi, M. capaccinii and $M$. schreibersii were also found to occur during the Middle Pleistocene of Grotta di Spinagallo (southeastern Sicily; see Kotsakis \& Petronio 1980). R. euryale, R. mehelyi,

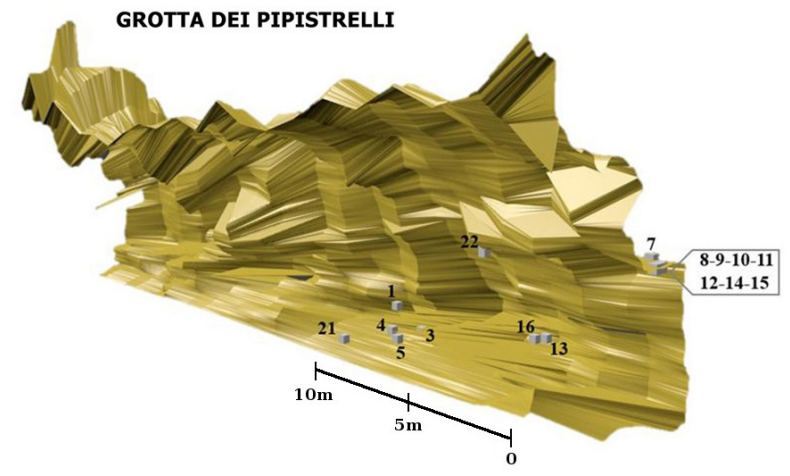

Fig. 3 - Grotta dei Pipistrelli (Sicily, Italy): 3D reconstruction of the right wall of the talus (image obtained using "Blender" program by C. Santoro); numbered cubes represent the pick points of specimens collected on sight.

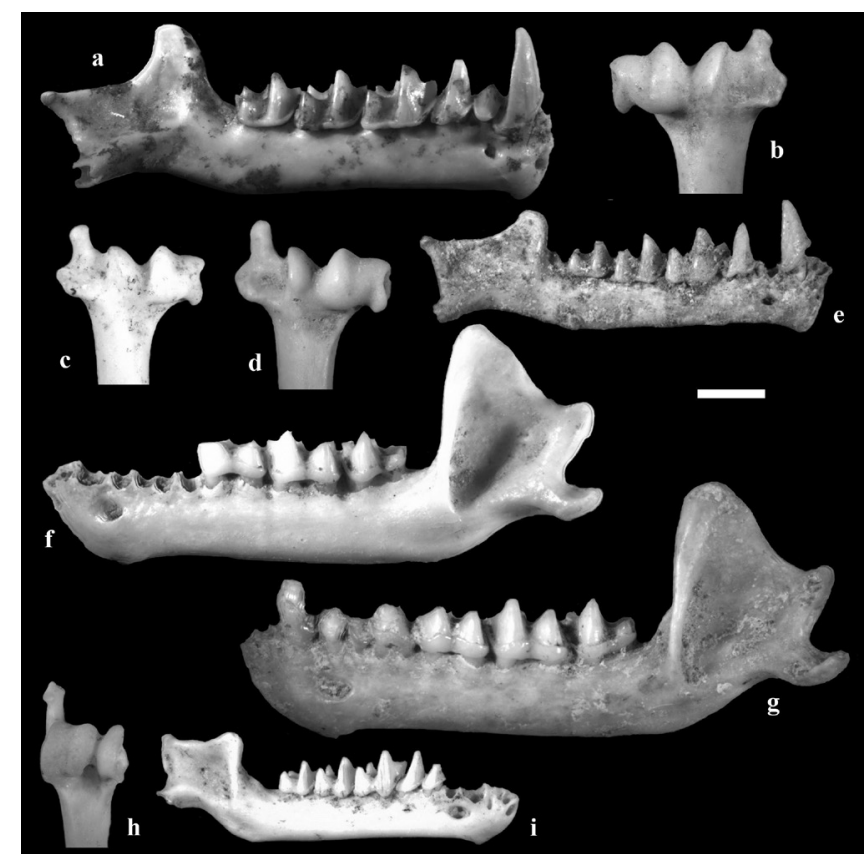

Fig. 4 - Grotta dei Pipistrelli (Sicily, Italy), Pleistocene: Rhinolophus ferrumequinum a) right mandible; b) left humerus; Rhinolophus euryale c) right humerus; Rhinolophus mehelyi d) right humerus; e) right mandible; Myotis blythii f) left mandible; Myotis myotis g) left mandible; Miniopterus schreibersii h) right humerus; i) right mandible (photos by L. Salari). Scale bar: $2 \mathrm{~mm}$. The distal epiphyses of the humeri are oriented according to Felten et al. (1973).

M. capaccinii and M. schreibersii were found in remains dating the Early and/or Late Pleistocene of Ghar Dalam Cave (Malta; see Storch 1974). Additionally, in a few other Sicily Pleistocene sites the generic occurrence of Myotis sp. (Mangano \& Bonfiglio 2005) or of undetermined Chiroptera (Bonfiglio et al. 2001) were reported. Thus, this preliminary study shows the first Pleistocene report of $R$. euryale in Sicily, and of M. myotis and M. blythii in the central Mediterranean islands.

The study of those fossil remains as well as the other collected samples (collected on sight, sediment samples and breccias), together with further analyses in the cave, including radiometric dating, can increase our knowledge on the taphonomy, chronology and palaeoecology on the fossil bat assemblage from the Grotta dei Pipistrelli and our understanding of ancient bat populations and the changing environmental conditions. 


\section{ACKNOWLEDGEMENTS}

We want to thank Nunzio Caruso ("Dipartimento Regionale Azienda Foreste Demaniali"), Filadelfo Brogna (Natural Reserve "Pantalica, Valle dell'Anapo e Torrente Cava Grande") and Tassos Kotsakis ("Roma Tre" University) for supporting and encouraging this research. We are also grateful to Angelo lemmolo, Giovanni Occhipinti and Francesco Zaccaria ("Speleo Club Ibleo") for the elaboration of the topographic map of the cave, to Katia F. Achino for the Resumen, to Gianna Innocenti for the revision of the English text, and to two anonymous reviewers for their critical and useful comments to our manuscript.

\section{REFERENCES}

AGNELLI, P., MARTINOLI, A., PATRIARCA, E., RUSSO, D., SCARAVELLI, D. \& GENOVESI, P. (2006). Guidelines for bat monitoring: methods for the study and conservation of bats in Italy. Quaderni di Conservazione della Natura, 19 bis, Min.Ambiente - Istituto Nazionale della Fauna Selvatica, Bologna, Italy, 200 pp.

AGNELLI, P., DI SALVO, I., RUSSO, D. \& SARÀ, M. (2008). Chirotterofauna della Sicilia (Mammalia, Chiroptera). In: AA.VV., Atlante della Biodiversità della Sicilia: Vertebrati terrestri. Studi e Ricerche 6, ARPA Sicilia, Palermo, pp. 25-40.

BONFIGLIO, L., MANGANO, G., MARRA, A.C. \& MASINI, F. (2001). A new late Pleistocene vertebrate faunal complex from Sicily (S. Teodoro Cave, North Eastern Sicily, Italy). Bollettino della Società Paleontologica Italiana, 40: 149158.

BONFIGLIO, L., AGNESI, V., MASINI, F. \& DI MAGGIO, C. (2004). Quaternary Eustatic Fluctuations and Biochronology of Vertebrate-Bearing Deposits Correlated with Marine Terraces in Sicily. APAT, Roma, Italy, 40 pp.

CARUSO, D. \& GRASSO, R. (1996). La fauna delle grotte. In: Ragonese, B. (ed.), Atti del Convegno "La fauna degli Iblei”, Noto (SR) 13-14 maggio 1995, Zangara Stampa, Siracusa, 201-281 pp.

FELTEN, H., HELFRICHT, A. \& STORCH, G. (1973). Die Bestimmung der europäischen Fledermäuse nach der distalen Epiphyse des Humerus. Senckenbergiana Biologica, 54: 291-297.

GRASSO, M. \& LENTINI, F. (1982). Sedimentary and tectonic evolution of the eastern Hyblean plateau (southeastern Sicily) during Late Creataceous to Quaternary time. Paleogeography Palaeoclimatology Palaeoecology, 39: 261-280. https://doi.org/10.1016/0031-0182(82)900256

GRASSO, R., AGNELLI, P., BROGNA, F., FRITTITTA, C. \& SPENA, M.T. in press. La chirotterofauna della Grotta dei Pipistrelli (SR). In: Atti del $5^{\circ}$ Congresso Regionale di Speleologia, Santa Ninfa (TP), 23-24 novembre 2013.
KOTSAKIS, T. \& PETRONIO C. (1980). I chirotteri del Pleistocene superiore della grotta di Spinagallo (Siracusa, Sicilia). Bollettino del Servizio Geologico d'Italia, 101: 4976.

LANZA, B. (2012). Fauna d'Italia. Mammalia V. Chiroptera. Edizioni Calderini de II Sole 24 Ore, Milano-Bologna,Italy, 800 pp.

MANGANO, G. \& BONFIGLIO, L. (2005). New stratigraphic and taphonomic data from the late Pleistocene deposits of the S. Teodoro Cave (North Eastern Sicily, Italy). Annali dell'Università degli Studi di Ferrara, Vol. spec. 2005: 8997.

MEIN, P. (1975). Les Chiroptères (Mammalia) du gisement pléistocène moyen des Abimes de la Fage à Noailles (Corrèze). Nouvelles Archives du Museum d'Histoire Naturelle de Lyon, 13: 57-67.

NIETHAMMER, J. \& KRAPP, F. (2001). Handbuch der Säugetiere Europas. Bd. 4: Fledertiere, Teil I: Chiroptera I. AULA-Verlag, Wiebelsheim, Germany, 603 pp.

SALARI, L. (2004). Contributo alla conoscenza dei resti ossei dei Chirotteri. Grotte e dintorni, 8: 45-54.

SALARI, L. \& DI CANZIO, E. (2009). I chirotteri del Pleistocene superiore e Olocene antico di alcune grotte dell'Italia centro-meridionale. Bollettino del Museo Civico di Storia Naturale di Verona, 33: 3-25.

SALARI, L. (2010). Lateglacial bats from the "M" layers of the Arene Candide Cave (Liguria, Italy). Rivista Italiana di Paleontologia e Stratigrafia, 116: 119-138. https://doi. org/10.13130/2039-4942/5944

SALARI, L. \& KOTSAKIS, T. (2011). Late Pleistocene and Holocene bats of Latium (Central Italy). II Quaternario, 24: 121-129.

SALARI, L., KOTSAKIS, T. \& PETRONIO, C. (2013). Early Pleistocene Bats from Pirro Nord (Apulia, Southern Italy). Palaeontographica, Abteilung A, 298: 55-72. hppt:// dx.doi.org/ 10.1127/pala/298/2013/55

SALARI, L. \& SILVESTRI, L. (2015). Holocene bats (Mammalia, Chiroptera) from five caves of Central Apennines (Italy). Journal of Bat Research \& Conservation, 8 (1): 27-41. http://dx.doi.org/10.14709/BarbJ.8.1.2015.06.

SCHILIRÒ, F., RUGGIERI, R. \& CANNATA, A. (2002). Necropoli di Pantalica: Carsismo e processi cinematici sul versante nord-orientale del Torrente Calcinara. Speleologia Iblea, 10: 59-74.

SCHILIRÒ, F., (2007). Stato tensionale nelle grotte carsiche di Pantalica (Grotta dei Pipistrelli). Speleologia Iblea, 12: 161-170.

SEVILLA GARCÍA, P. (1988). Estudio paleontologico de los quirópteros del Cuaternario español. Paleontologia $i$ Evolució, 22: 113-233. 
SPENA, M.T., ALLEGRA FILOSICO, M., BROGNA, F., DIPASQUALE, C., PUMA, A., GRASSO, R. \& AGNELLI, P. (2013). I chirotteri della Grotta dei Pipistrelli (SR): un unicum nella Sicilia sud-orientale. Atti della Società dei Naturalisti e Matematici di Modena, 144: 171.

STORCH, G. (1974). Quartäre Fledermaus-Faunen von der Insel Malta. Senckenbergiana Lethaea, 55: 407-434.
TATA, C. \& KOTSAKIS, T. (2005). Italian fossil chiropteran assemblages: a preliminary report. Geo.Alp, 2: 53-60.

TOPÁL, G. \& TUSNADI, G. (1963). Data for craniometric investigation of Myotis myotis Borkh. and Myotis oxygnathus Montic. in Hungary. Annales HistoricoNaturales Musei Nationalis Hungarici, 55: 543-549. 